Catalyst Papers in Press are peer-reviewed, accepted articles that have not yet been edited or formatted, but may be cited by DOI. The final version may contain substantive or nonsubstantive changes.

\title{
Grapevine Virus E Detected in Ohio Vineyards
}

${ }^{1}$ Department of Plant Pathology, The Ohio State University-Wooster Campus, Wooster, OH 44691; and ${ }^{2}$ United States Department of Agriculture, Agricultural Research Service, Department of Crop Sciences, University of Illinois, Urbana, IL 61810.

9 *Corresponding author (Ivey.14@osu.edu; tel: 330-263-3849)

10 Manuscript submitted June 10, 2020, revised Sept 16, 2020, accepted Sept 22, 2020

11 This is an open access article distributed under the CC BY license (https://creativecommons.org/ 12 licenses/by/4.0/).

13 By downloading and/or receiving this article, you agree to the Disclaimer of Warranties and Liability.

14 The full statement of the Disclaimers is available at https://www.asevcatalyst.org/content/proprietary-

15 rights-notice-catalyst. If you do not agree to the Disclaimers, do not download and/or accept this article.

16 Key words: grapevine virus E, Ohio, virus surveys, viruses

\section{Summary}

Wine grape production in Ohio is challenging due to unpredictable winter temperatures,

19 late and/or early frosts, a short growing season and a plethora of diseases that can reduce yield

20 and grape quality. Around the world, studies have shown that the impact of viral diseases in

21 vineyards can result in a significant reduction in economic returns due to reduced yield or

22 diminished fruit quality. From 2012 to 2016, surveys for major viruses in commercial wine

23 grapes were conducted in order to obtain a comprehensive understanding of the prevalence of

24 viral diseases in Ohio vineyards. To date, these surveys have shown that Grape leafroll

25 associated viruses $2(\mathrm{GLRaV}-2)$ and $3(\mathrm{GLRaV}-3)$ and Grapevine red blotch virus (GRBV) are

26 present in commercial vines across the state $(1,2)$. In this study we report that Grapevine virus 
Catalyst Papers in Press are peer-reviewed, accepted articles that have not yet been edited or formatted, but may be cited by DOI. The final version may contain substantive or nonsubstantive changes.

doi: $10.5344 /$ catalyst.2020.20006

$27 E(\mathrm{GVE})$ is also present in Ohio grapevines, further increasing our knowledge of the types of

28 grapevine viruses present in the state.

Over 80 viruses are known to infect grapevines, more than any other perennial crop (3).

30 Grapevines can be infected with a single virus or multiple viruses. In addition, synergistic

31 interactions between grapevine viruses from different virus families have recently been reported

32 (4). Grapevine viruses are transmitted by insect, nematode, or eriophyid mite vectors and all

33 grapevine viruses can be spread from region to region through the distribution of infected

34 vegetative cuttings (5). The impact of viruses on grapevines varies considerably depending on

35 the incidence, distribution, presence of coinfections or synergistic interactions, and available

36 control strategies of the infecting viruses. While some viruses do not cause symptoms and/or

37 direct economic losses, others can reduce plant growth, vigor, and berry quality, or kill the vine

38 (5). Nonetheless, all viruses should be considered equally important with respect to maintaining

39 clean stock programs and the sanitary status of vineyards across the country.

$40 \quad$ Grapevine virus $E(\mathrm{GVE})$ is a relatively new virus associated with grapevines worldwide.

41 It was first described in 2018 in Japanese table grape (Vitis labrusca cv. Aki Queen and Pione)

42 and classified as a new member of the genus Vitivirus (6). Since 2008, GVE has been reported

43 in South Africa (7), China (8), Tunisia (9), Washington state (USA) (10), Argentina (11) and

44 Greece (12). The virus has been isolated from visibly healthy vines $(6,10-11)$, vines with stem

45 pitting symptoms (6), vines with leafroll and Shiraz disease symptoms (7), and vines with rugose

46 wood disease complex (13). GVE can be transmitted non-persistently by the Comstock

47 mealybug (Pseudococcus comstocki Kuwanae) (6) and although mechanical transmission is not 
Catalyst Papers in Press are peer-reviewed, accepted articles that have not yet been edited or formatted, but may be cited by DOI. The final version may contain substantive or nonsubstantive changes.

suspected (6) the virus is likely spread from region to region through the movement of infected vegetative cuttings. While the role of GVE in causing disease and displaying symptoms has yet to be deciphered, it has been reported to correlate with higher incidence and titer of other

51 vitiviruses (i.e. Grapevine virus $A$ and Grapevine virus $B$ ) and increased disease severity in vines

52 coinfected with the economically important viruses GLRaV-2 and/or 3 GLRaV-3 (4, 14-15).

53 Thus, the potential for increased severity of disease in vines coinfected with GVE, GLRaV-2 and/or $3 \mathrm{GLRaV}-3$ is possible and needs to be further explored.

Monitoring for the presence of known and unknown viruses in high value crops such as grape is essential to targeting and implementing control measures of potentially devastating new or existing viral diseases. At the request of the Ohio wine grape industry a study to characterize the viruses infecting grapevines was conducted between 2012 and 2016. Grapevine leaves with virus-like symptoms including leaf curling or thickening, interveinal leaf reddening, vine stunting, delayed fruit maturity and/or red or yellow leaf discoloration (blotching) were collected

61 from 40 vineyards across seven wine grape growing regions (Northeast, Lake shore, Northwest,

62 Canal country, Central, Southwest, and Appalachian) in the state. Through high-throughput

63 RNA sequencing (RNAseq) we discovered the near complete sequence of a new GVE isolate in

64 the state of Ohio. High-throughput sequencing (HTS) technology has revolutionized the field of

65 virology by allowing for the rapid and precise genetic and evolutionary analyses of viral

66 populations in diverse sample types (16-17). In grapevines, HTS allows for the assembly of

67 complete genomes of the various types of viruses that could be infecting the vines $(16,18)$. In

68 this study we pooled collected grapevine leaves $(n=140)$ by growing region, generated seven 
Catalyst Papers in Press are peer-reviewed, accepted articles that have not yet been edited or formatted, but may be cited by DOI. The final version may contain substantive or nonsubstantive changes.

doi: $10.5344 /$ catalyst.2020.20006

RNAseq datasets and retrieved six assembled sequences (contigs) that ranged in size from 677 to

2,648 nucleotides (nt). These six contigs were compared to published viral sequences in the NIH

71 genetic sequence database (GenBank) and were shown to share sequence identity (73-91\%) with

72 a GVE isolate from South Africa (SA94, GU903012.1) (7). Overall, the two isolates share 77\%

73 nt level sequence identity. A nearly complete (7, $530 \mathrm{nt})$ genomic sequence of GVE (GVE-OH)

74 was assembled from the contigs and the final sequence was deposited in GenBank under the

75 accession number MK331711. Although the sequence is missing approximately $25 \mathrm{nt}$, the Ohio

76 isolate is predicted to encode four proteins that share similar amino acid sequences with those in

77 the South African isolate (7). These proteins are predicted to function in virion assembly (capsid

78 protein, $95 \%$ amino acid (aa) sequence similarity), cell-to-cell movement (movement protein,

$7980 \%$ ), and genome replication (replicase, $82 \%$ ) processes within host cells, as well as an as-yet-

80 uncharacterized protein (putative nucleic acid binding protein, $93 \%$ ).

GVE-OH was traced back to two different vineyards (Lake shore and central growing

82 regions) more than 100 miles apart, both of which were also positive for GLRaV-2 and -3 (1).

83 This is the first report of GVE in $\mathrm{OH}$ vineyards and of GVE in wine grape production areas east

84 of the Rocky Mountains. These results also confirm that co-infections of GVE with one or more

85 GLRaV are occurring, which is not unexpected as both viruses can be transmitted by mealybugs,

86 spread through the movement of propagation material, and mixed viral infections in grapevines

87 are common (19). Given the fact that GVE was detected in two vineyards separated by more

88 than 100 miles, GVE was likely introduced into these vineyards through propagative material,

89 emphasizing the importance of surveys to monitor for the early detection and management of 
Catalyst Papers in Press are peer-reviewed, accepted articles that have not yet been edited or formatted, but may be cited by DOI. The final version may contain substantive or nonsubstantive changes.

infected vines and planting certified virus tested planting material. In Ohio, widespread testing is

91 recommended to confirm the distribution of GVE in the grape growing regions of the state, the

92 primary method of dispersion and whether or not there is a synergistic interaction occurring in

93 vines with GVE, GLRaV-2 and -3 coinfections.

\section{References and Footnotes}

1. Han J, Ellis M and Qu F. 2014. First Report of Grapevine leaf roll-associated virus-2 and -3 in Ohio Vineyards. Plant Dis. 98:284.

2. Yao XL, Han J, Domier L, Qu F and Lewis Ivey, ML. 2017. First report of Grapevine red blotch virus in Ohio vineyards. Plant Dis. 102:463.

3. Martelli GP. 2017. Overview on grapevine viruses, viroids, and the diseases they cause. In A Grapevine Viruses: Molecular Biology, Diagnostics and Management. Meng B, Martelli G, Golino D, Fuchs M, (eds.), Springer, Cham.

4. Rowhani, A., Daubert, S., Arnold, K., Al Rwahnih, M., Klaassen, V., Golino, D., and Uyemoto, J.K. 2018. Synergy between grapevine vitiviruses and grapevine leafroll viruses. Euro. J. Plant Pathol. 151:919-925.

5. Fuchs, M. 2020. Grapevine viruses: a multitude of diverse species with simple but overall poorly adopted management solutions in the vineyard. J. Plant Pathol. 102:643653.

6. Nakaune R, Toda S, Mochizuki M, and Nakano M. 2008. Identification and characterization of a new vitivirus from grapevine. Arch. Virol. 153:1827-1832.

7. Coetzee B, Maree H, Stephan D, and Freeborough MJ. 2010. The first complete nucleotide sequence of a Grapevine virus $E$ variant. Arch. Virol. 400:157-16.

8. Xudong F, Dong Y-F, Zhang ZP, Ren, F, Hu G-J and Zhu, HJ. 2013. First report of Grapevine virus $E$ from grapevines in China. J. Plant. Pathol. 95: 659-668.

9. Selmi I, Lehad A, Pacifico D, Carimi F, and Mahfoudhi N. 2017. First Report of Grapevine virus $E$ and Grapevine virus $F$ in Tunisian grapevines. J. Plant. Pathol. 99:543.

10. Alabi OJ, Poojari S, Sarver K, and Martin R. 2013. Complete genome sequence analysis of an American isolate of Grapevine virus E. Virus Genes 46:563-566.

11. Debat H, Zavallo D, Luna F, Moyano, S, Asurmendi, S, and Gomez-Talquenca S. 2019. First report of Grapevine virus E infecting grapevine in Argentina. J. Plant. Pathol. 101:1239. 
Catalyst Papers in Press are peer-reviewed, accepted articles that have not yet been edited or formatted, but may be cited by DOI. The final version may contain substantive or nonsubstantive changes.

doi: 10.5344/catalyst.2020.20006

12. Panailidou P, Lotos L, Olmos A, Ruiz-Garcia AB, Moran F, Orfanidou CG, Sassalou CL, Katis, NI and Maliogka VI. 2019. First report of Grapevine virus $E$ and Grapevine virus $F$ in grapevine in Greece. Plant Dis. 103.

13. Al Rwahnih M, Sudarshana MR, Uyemoto JK and Rowhani A. 2012. Complete genome sequence of a novel vitivirus isolated from grapevine. Virol. J. 86:9545-9545.

14. Rowhani, A., Uyemoto, J. K., Golino, D., Daubert, S. D., \& Al Rwahnih, M. (2016). Viruses involved in graftincompatibility and decline. In B. Meng, M. Fuchs, G. Martelli, \& D. Golino (Eds.), Grapevine viruses: Molecular biology, diagnostics, and management, Chapter 12 (pp. 289-302). New York: Springer.

15. Golino, D., Rowhani, A., Klaassen,V., Sim, S.,\& Al Rwahnih, M. (2015). Grapevine leafroll associated virus 1 effects on different grapevine rootstocks. In Proceedings of the 18th international congress on virus and virus-like diseases of grapevine (pp. 46-47). Ankara.

16. Al Rwahnih, M., Daubert, S., Golino, D., Islas, C., and Rowhani, A. 2015. Comparison of next-generation sequencing versus biological indexing for the optimal detection of viral pathogens of grapevines. Phytopathology 105:758-763.

17. Villamor, D.E.V., Al Rwahnih, M. Martin, R.R., and Tzanetaki, I.E. 2019 High throughput sequencing for plant virus detection and discovery. Phytopathology 109:716725.

18. Al Rwahnih, M., Daubert, S., Golino, D., and Rowhani, A. 2009. Deep sequencing analysis of RNAs from a grapevine showing Syrah decline symptoms reveals a multiple virus infection that includes a novel virus. Virology 387:395-401.

19. Xiao H, Shabanian M, Moore C, Li C and Meng B. 2018. Survey for major viruses in commercial Vitis vinifera wine grapes in Ontario. Virol. J. 15:127. 